\title{
Economic Growth and the Public Sector: A Comparison of Canada and Italy, 1870-2013
}

\author{
LIVIO DI MATTEO, \\ Lakehead University and RCEA* \\ THOMAS BARBIERO \\ Ryerson University and RCEA
}

\begin{abstract}
There is considerable evidence that the size of the public sector can influence an economy's rate of economic growth. We investigate public sector spending of central governments and economic performance in two G7 countries over the long-term, Canada and Italy. Their economic performance has diverged in the last 25 years and it is worth investigating whether the size of government was a contributing factor. We find that in both the case of Canada and Italy the size of central government spending directly affects the performance of their economies in an inverse U-shaped relationship known as a Scully/BARS Curve. These results suggest that along with modifying current central government size, other levels of governments may need to shrink their own spending. The fact that the amount spent by government on pensions as a percentage of GDP in Italy is nearly 4 times that in Canada may partly explain the higher level of Italy's public debt as well as an indirect contributing factor to economic stagnation in the last 25 years.
\end{abstract}

Keywords: N10; N12; N14; H5; O38

JEL Classifications: Economic History, Canada, Italy, Government Size, Economic Growth

\section{Introduction}

Canada and Italy were both founded as modern states in the mid-nineteenth century: Canada in 1867 and Italy in 1861. They have both evolved over time into advanced developed countries with high standards of living and are members of the G-7. Though they have obvious differences of history, language and culture, there are also some interesting parallels and similarities. Aside from being relatively new countries, both countries started as constitutional monarchies and more significantly, both have strong regional economic

\footnotetext{
* The authors wish to acknowledge the research assistance of Ugochi Emenogu, Ryerson University. The paper has also benefited from the feedback of Leo Michelis and Brennan Thompson, both in the Department of Economics at Ryerson University.

(C) 2018 Livio Di Matteo and Thomas Barbiero. Licensed under the Creative Commons Attribution Noncommercial 3.0 License (http://creativecommons.org/licenses/by-nc/3.0/. Available at http: //rofea.org.
} 
variations. These regional variations have resulted in important nation building roles for government in both countries.

As well, both countries were founded on principles rooted in classical liberal economic thought, though over time these roots have diminished in Italy much more so than in Canada. The founders of the Canadian federation at their core had a vision of government founded in civil liberties $^{1}$ and the role of government in economic development as the provider of a framework to allow individuals to pursue wealth and property. ${ }^{2}$ Mingardi (2017: 22) notes that Italy has always had a vein of liberal thought, but it has since the 1860s been "but one thin trace in Italy's mostly illiberal political thought and culture," and while vocal does not appear to have been highly successful in affecting public policy.

A public sector role in economic development and activity nevertheless emerged in both countries. In Canada, the federal government served as an entrepreneur helping build the eastwest economy via the nineteenth century National Policies of land settlement, tariffs and railway subsidization ${ }^{3}$. In the twentieth century, the federal government's national building role has evolved into one of fiscal transfers, which have attempted to equalize resources across the federation. In the case of Italy, the central government dealt with the demands of industrialization and regional economic tensions between north and south and the public sector has also performed a nation-building role. For example, in 1950 "La Cassa per il Mezzogiorno," a publicly funded investment fund, was created to help finance industrial development in the South so as to close the sizable gap with the North ${ }^{4}$.

The role of the state in economic growth and development is constantly debated, and the $21^{\text {st }}$ century is no exception. No one doubts that the state can assist economic growth and development, but there is no established consensus as to the optimal amount of state participation in economic affairs that will yield the most growth. Generally, those that believe that markets do a relatively good job of promoting economic growth and development frown upon government intervention.

There is also the question of the type of government involvement in the economy of a nation. Generally, most economists agree that government investment in infrastructure development is often complementary to private investment and can help promote economic growth. Roads, airports and rail lines are a case in point. Moreover, where governments

\footnotetext{
${ }^{1}$ These civil liberties were limits on a government's activities and marked out areas of individual freedom and responsibility: freedom from arbitrary arrest or detention, freedom of speech, freedom of worship, freedom to elect a government and freedom from oppression by authority. See Ajzenstat (2010: 9).

2 As noted by La Forest (1967: 1)" "During the period around 1867, the philosophy of laissez faire was at its zenith; governmental activity was narrowly restricted, and in consequence so too were governmental expenses."

${ }^{3}$ It has been argued that the National Policy tariffs of 1879 did not have a meaningful impact on the subsequent rate of economic growth in Canada. See Hinton et. al.

${ }^{4}$ For an overview of the development policies for southern Italy, see Chenery (1962), and Lutz (1962).
} 
redistribute income through the tax system in a manner that hinders output growth but stimulates consumption, we usually see sluggish economic growth.

This paper compares the role government in Canada and Italy played in fostering economic growth by comparing the relationship between real GDP growth, public sector size and the debt to GDP ratio over the long term. The reason for doing so is the divergent path of economic growth in the two countries over approximately the last 25 years, despite both being members of the $\mathrm{G} 7$ countries, thus allowing comparison between two economies at equivalent level of economic development. We investigate whether the size of government can explain at least some of the difference in economic performance. A traditional definition of public sector size is used: government spending as a share of GDP. Regression analysis is employed to see the direct effect of this variable on economic growth and the impact is interpreted within a broader discussion of government policy in the long run with respect to protectionism and redistribution.

While both countries have engaged in more protectionist trade policies prior to 1945 , and redistributive activity in the post- WWII period, the stronger tendency of Italian public life and policy towards illiberal political economy and philosophies has meant a larger public sector, and a greater tendency towards deficits and debt. Our results find a hump-shaped Scully/BARS curve for both Canada and Italy. The Scully/BARS curve refers to a relationship between government size and economic growth whose peak represents an estimate of the optimum size of government that maximizes a country's economic growth. However, based on current figures it would appear that Canada's central government expenditure to GDP is slightly below its GDP growth maximizing size while Italy's is larger. The possible reasons for this are explored in the subsequent qualitative discussion but a key feature is the greater role of government pension and social spending in Italy relative to Canada.

The paper is organized as follows. In section 2 we review the pertinent literature on the Scully/BARS curve; section 3 gives an overview of government size in Canada and Italy from 1870 to 2013, as proxied by government expenditures; section 4 sets out our econometric model and reports our results; section 5 discusses the results and policy implications, followed by conclusions.

\section{Public Sector and Economic Performance: Literature Review}

Economists have focused on more specific and tractable aspects of the relationship between government and economic growth and performance. ${ }^{5}$ For the most part, the literature shows

\footnotetext{
${ }^{5}$ For an overview of economic growth theories, the role of government and institutional factors in growth, see Bergh and Henrekson (2011), Solow (1994), and Romer (1994), Barro (1990), North (1987, 1990), Rodrik (2007), Rodrik et al., (2004), Abdiweli (2003), Asoni (2008) and Sturm and De Haan (2001).
} 
that after a certain level, increasing government size, along with increasing level of government debt is generally not conducive to economic growth. For example, Barro (1990) argues that government spending on institutional infrastructure such as property rights is beneficial, but as government spending levels rise, economic growth rates eventually decline, particularly if the rise in spending is directed toward consumption of goods and services. For the period 1960 to 1985, Barro (1991) examines the growth rate of real per capita GDP in 98 countries and finds economic growth inversely related to the share of government consumption in GDP. ${ }^{6}$ However, Barro also finds found growth rates positively related to human capital as measured by school enrolment and political stability, and inversely related to market price distortions as proxied by purchasing power parity prices for investment goods.

The relationship known as the Armey Curve (Armey 1995), posits a hump-shaped relationship between government size and the rate of economic growth - a relationship also referred to as the BARS curve (Barro, Armey, Rahn and Scully). ${ }^{7}$ As the public sector first expands, it has a positive effect on economic growth as the state develops and provides infrastructure to complement private sector activity. However, beyond a certain point, the public sector begins diverting resources into less productive uses, facilitating rent seeking and requiring higher taxes to finance the expanding state. Higher taxes after a certain point are found to reduce economic growth.

Whether the public sector has a positive or negative effect on economic growth in a country is ultimately an empirical question with cross-section and country specific studies. Indeed, many studies point to a negative relation between the size of government and economic growth. For less developed countries, Landau (1983) finds government size negatively correlated with the growth of per capita GDP. Marlow (1986) finds a negative relationship between public sector size and economic growth over the 1960 to 1970 period for industrialized countries. Grier and Tullock (1989) examine post-war economic growth in 113 countries and find government consumption expenditures negatively correlated with economic growth in three out of four of their sub-samples, including the OECD countries.

Scully (1989) uses economic growth data for 115 economies over the period 1960 to 1980 and finds nations with relatively large government shares in 1960 generally grew more slowly than nations with relatively small state sectors. Scully (1991) looks at the relationship between government size -measured as the tax to GDP ratio - and economic growth for 103 countries over the 1960 to 1980 period and finds rates of economic growth maximized with government size at about 19 percent of GDP. Indeed, the Scully Curve (1989, 1991, 1994,

\footnotetext{
${ }^{6}$ Furthermore, Alesina et al., (2002) examines 16 OECD countries over the period 1960 to 1996 and finds an inverse relationship between increases in government spending and private sector investment, with negative consequences for the rate of economic growth.

${ }^{7}$ See also Forte and Magazzino (2010, 2011).
} 
2000) in particular aims to present a growth maximizing or optimal size of government estimate.

Romero-Avila and Strauch (2008) examine 15 European Union countries from 1960 to 2001 and find that government size as measured either with total expenditure or revenue shares of GDP, government consumption and direct taxation negatively affect growth rates of GDP per capita, while public investment had a positive impact. Forte and Magazzino (2011) show for the EU-27 member states, an inverse u-shaped public sector size economic growth relationship with a peak attained for an expenditure of $37.29 \%$ of GDP, while the average ratio is $47.90 \%$.

Bergh and Karlsson (2010) examine the relationship between government size and growth while also controlling for institutional quality measures of economic freedom and the impact of globalization. Using data from 29 OECD countries from 1970 to 1995, they find government size robustly correlates negatively with growth. As well, they find some evidence that countries with big government can use economic openness and market oriented economic policies to mitigate negative effects of big government.

Afonso and Furceri (2010) look at the size, composition and volatility of government revenues and expenditures on growth in the OECD and EU countries for the period 1970 to 2004. They find that the size and volatility of indirect taxes, social contributions and government consumption spending have a sizeable, negative and statistically significant effect on economic growth. Specifically, a percentage point increase in the share of total revenue (total expenditure) would decrease output by 0.12 and 0.13 percentage points respectively for the OECD and for the EU countries. On the other hand, the size of subsidies and the volatility of government investment have a negative and significant effect on growth.

Afonso and Jalles (2011) conduct an empirical analysis of 108 countries over the period 1970 to 2008 that includes variables for government size as well as institutional quality. Their results find a negative effect of the size of government on economic growth while institutional quality has a positive impact on real economic growth. Moreover, they find that institutional quality variables such as regime durability, governance and extent of democracy have a stronger positive impact on growth when governments are smaller.

Folster and Henrekson (2001) conduct an econometric panel study on a sample of rich countries over the 1970 to 1995 period and find a strong and significant negative relationship between government expenditure and economic growth. The size of the estimated coefficients implies that an increase of the expenditure to GDP ratio by 10 percentage points is associated with a decrease in the annual growth rate on the order of $0.7-0.8$ percentage points.

It should be noted that not all studies have reported a negative relationship between the size of government and economic growth. Blanchard and Perotti (2002) examine the effect of government spending shocks in the U.S. economy during the post-war period and find that positive government expenditure shocks have a positive effect on output while positive tax 
shocks have a negative effect. However, both increases in taxes and increases in government spending have a strong negative effect on investment spending.

In terms of making the case for larger government, Atkinson (1995) argues that the transfers of the welfare state such as state pensions and their effects on savings and investment are not necessarily an obstacle to economic growth. ${ }^{8}$ Empirically, Ram (1986) using the same data as Landau concluded that the relationship between public sector size and GDP growth was positive. Rubinson (1977) and Grossman (1988) for Australia also find evidence of a positive relationship between public sector size and economic growth. More recently, Colombier (2009) using OECD data also finds a positive effect between government size and economic growth.

Studies by Slemrod (1995) and Tanzi and Zee (1997) find a negative relationship between government size and economic growth, but only beyond a threshold size of government. This is in keeping with the argument by Folster and Henrekson (2001) that countries with large public sectors devote a smaller share of those expenditures to promoting private sector activity relative to countries with smaller governments. The negative effects of larger public sector size can be greater in non-democratic as opposed to democratic countries, suggesting that institutional differences can again be a factor in the effects of government size on economic growth and performance.

Bergh and Henrekson (2011) argue that studies of government size and economic growth sometimes produce conflicting results because they employ different definitions of government size and use a diverse mix of countries. They propose limiting the focus of studies to rich countries. Limiting their analysis to more highly developed rich countries, they obtain more consistent results that show a significant negative correlation: increasing government size by 10 percentage points is associated with a 0.5 to 1 percent lower annual economic growth rate. Moreover, they note the example of several countries (Scandinavian countries) that seem to have high taxes and above average growth and note that these countries may have institutional compensating factors in the form of higher social trust levels or market friendly policies in other areas.

Single nation studies have also been a feature of the public sector size and economic growth literature and highlight conclusions that efficient government size may have countryspecific features. Facchini and Melki (2013) analyze the non-linear time-series relationship between public spending and GDP for France between 1896 and 2008 and find that efficient government size was reached at about 30 percent of GDP. Moreover, the government size that maximizes output has been continuously exceeded in France since the 1950s. Ferris and Voia (2015) for Canada find that finds the inverted $U$ shape to be consistent with the data

\footnotetext{
${ }^{8}$ For example, the net effects of state pensions on saving and economic growth depend on the determinants of savings and whether or not such saving is automatically translated into investment spending. See Atkinson (1995).
} 
only for the 1870-1936 time-period. After World War II, federal size was above peak size suggesting that such increases have imposed costs on economic growth.

Forte and Magazzino (2016) assess the relationship between government size and economic growth in Italy over the period 1861 to 2008 . They find a non-linear relationship between the size of the public sector (measured by the share of government expenditure over GDP) and the economic growth rate for Italy. This is not surprising when investigating such a long period of time. But their results show unambiguously that in the latter part of the long period they look at "...the great average increase of public expenditure is accompanied by more than a proportional decline in the GDP growth rate." (p.156) Their findings confirm the BARS's relationship for the case of Italy.

Thus, there is a general consensus in the literature that as the size of the government (as measured by government expenditures as a percentage of GDP) increases beyond a threshold, the growth rate of GDP slows. We contribute to the literature by focusing on Canada and Italy to analyze the growth of government as a percentage of GDP and their economic performance. Both are members of the G7 countries, but their rates of growth have diverged significantly in the last quarter century. We suggest possible explanations for the divergence in economic performance focused on differences in the redistributive activities of the state.

\section{Canada and Italy: Some Facts on Government Spending and Economic Growth Over Time}

The data for Canada and Italy analyzed here is from the Jordà-Schularick-Taylor (JST) Macrohistory Database ${ }^{9}$ a comprehensive macro-financial dataset consisting of 29 time series variables for 17 countries from 1870 to $2013 .{ }^{10}$ The data set and documentation are available at: http://www.macrohistory.net/data. Table 1 presents the average annual growth rate of real per capita GDP for Canada and Italy for the period 1871 to 2013 as well as data broken down by specific time periods: the era of the first great globalization from 1871 to 1913 , the war and depression era from 1914 to 1945, the post-war boom era from 1946 to 1973 and the period since 1974 which marks the productivity slowdown. As a result of the impact of World War II on growth rates particularly for Italy, two additional growth periods are included to take these outlier years into account: 1914 to 1939 and 1947 to 1973.

\footnotetext{
9 "Òscar Jordà, Moritz Schularick, and Alan M. Taylor. (2017). "Macrofinancial History and the New Business Cycle Facts," in NBER Macroeconomics Annual 2016, volume 31, edited by Martin Eichenbaum and Jonathan A. Parker. Chicago: University of Chicago Press." Accessed October 2016.

${ }^{10}$ The 17 countries in the data set are Australia, Belgium, Canada, Denmark, Finland, France, Germany, Italy, Japan, Netherlands, Norway, Portugal, Spain, Sweden, Switzerland, United Kingdom, and the USA.
} 
Review of Economic Analysis 10 (2018) 221-243

Table 1: Average Annual Growth Rate of Real Per Capita GDP

\begin{tabular}{|l||c|c|c|c|c|c|c|}
\hline & $\begin{array}{c}1871- \\
2013\end{array}$ & $\begin{array}{c}1871- \\
1913\end{array}$ & $\begin{array}{c}1914- \\
1945\end{array}$ & $\begin{array}{c}1914- \\
1939\end{array}$ & $\begin{array}{c}1946- \\
1973\end{array}$ & $\begin{array}{c}1947- \\
1973\end{array}$ & $\begin{array}{c}1974- \\
2013\end{array}$ \\
\hline \hline Italy & 1.9 & 1.0 & -0.9 & 1.1 & 7.0 & 6.0 & 1.5 \\
\hline Canada & 2.1 & 2.4 & 1.8 & 0.6 & 2.4 & 2.6 & 1.7 \\
\hline Average -17 Countries & 2.0 & 1.5 & 0.9 & 1.4 & 4.3 & 4.1 & 1.8 \\
\hline
\end{tabular}

Source: Computed from the Jordà-Schularick-Taylor (JST) Macrohistory Database

Over the period 1871 to 2013, real per capita GDP across these 17 countries averaged an annual growth rate of 2.1 percent, with Canada averaging 2.1 percent and Italy 1.9 percent. In terms of performance across sub-periods, growth was highest on average during the post-war boom era between 1947 and 1973 at 6 percent for Italy and 2.6 percent for Canada. ${ }^{11}$ Indeed, Italy substantially outperforms Canada during this period in terms of growth rate, though not the level of real per capita GDP.

Table 2 presents the government expenditure to GDP ratios for Canada and Italy for the period 1871 to 2013, and again for the time sub-periods used in Table 1. It should be noted that the government expenditure variable refers only to central government expenditure, which implies that the public sector size variables are underestimated for countries with federal forms of government: namely, Canada, with respect to Italy. ${ }^{12}$ Public sector size is generally higher in Italy than in Canada in the JST dataset because provincial spending which is quite large in Canada - is not included in the Canadian figures. However, the Canadian and Italian data in the Jordà-Schularick-Taylor (JST) Macrohistory Database are comparable because both sets of numbers refer only to central government expenditures.

What stands out in Table 2 is the rapid growth of the percentage of GDP going to central government in Italy, from about 19 percent in the 1946-73 period to 33 percent for 19742013. The equivalent Canadian percentage rises from approximately 16 percent to 20 percent. We now inquire whether there may be a possible link between the differential government sector size in the two countries and their respective GDP growth rates.

\footnotetext{
${ }^{11}$ It should be noted that for the 1946-1973 the respective growth rates for Canada and Italy were 2.4 and 7 percent.

${ }^{12}$ In Canada, the federal share of total government spending was approximately 40 percent prior to World War I. After the peak of over 70 percent reached during World War I, the federal share came down quickly but went up again during the Depression era and soared during World War II reaching over 90 percent. The federal share of spending came down more gradually after World War II levelling off at almost 50 percent during the 1970s and 1980s before falling once again to about 40 percent during the 1990s. See: http://www.macleans.ca/economy/economicanalysis/the-mostimportant-economic-charts-to-watch-in-2018/\#liviodimatteo
} 
DI MATTEO, BARBIERO Economic Growth and Public Sector in Canada and Italy 1870-2013

Table 2: Average Government Expenditure to GDP Ratio

\begin{tabular}{|l||c|c|c|c|c|c|c|}
\hline & $1871-$ & $1871-$ & $1914-$ & $1914-$ & $1946-$ & $1947-$ & $\begin{array}{c}1974- \\
1913\end{array}$ \\
\hline \hline Italy & 0.23 & 0.138 & 0.257 & 0.231 & 0.193 & 0.191 & 0.334 \\
\hline Canada & 0.14 & 0.065 & 0.137 & 0.102 & 0.164 & 0.155 & 0.195 \\
\hline AVERAGE-17 Countries & 0.17 & 0.073 & 0.155 & 0.131 & 0.194 & 0.191 & 0.259 \\
\hline
\end{tabular}

Source: Computed from the Jordà-Schularick-Taylor (JST) Macrohistory Database

\section{Model and Estimates}

Separate regressions for Canada and Italy are used to estimate the relationship between economic growth and public sector size. Based on the literature, the following model was specified as:

$$
\begin{aligned}
y_{t} & =A_{0}+A_{1} \text { govtogdp }_{t}+A_{2} \text { govtogdp }_{t}+A_{3} w w 1_{t}+A_{4} W w 2_{t}+ \\
& +A_{5} \text { debttogdp }_{t}+A_{6} \text { Itrate }_{t}+A_{7} \text { exptogdp }_{t}+A_{8} \text { rgdpmad }_{t-1}+ \\
& +A_{9} \text { rgdpcgrowth }_{t-1}+A_{10} \text { GrDepression }_{t}+u_{t}
\end{aligned}
$$

The dependent economic growth variable, $y_{\mathrm{t}}$ is real GDP growth as constructed from variables for nominal GDP and CPI. This variable is regressed on the ratio of central government expenditure to GDP, govtogdp $t_{t}$, as well as govtogdpsq ${ }_{t}^{2}$ - central government expenditure to GDP squared as the specification to capture the Scully/BARS Curve. Other explanatory variables include debt to GDP ratio, debtgdp $p_{t}$, to account for the effect of public debt on economic growth, long-term interest rate, Itrate $_{t}$, and export to GDP ratio, exptogdp $p_{t}$, to capture the impact of trade on economic growth. There are also dummy variables $w w 1_{t}$ for World War I (1914-18), ww2 ${ }_{t}$ for World War II (1939-45), and GrDepression ${ }_{t}$ for the Great Depression (1929-1933) to capture any shift effects from these events.

We also include the one-year lagged value of real per capita GDP, $\operatorname{rgdpmad}_{t-1,}$ and the oneyear lagged growth rate of real per capita GDP, rgdpcgrowth ${ }_{t-1}$. The lagged variables are included to allow for the effects of persistence and adjustment to economic change over time. Initial specifications also included a dummy variable for the Fascist Era in Italy, but it was found to be insignificant. These variables were selected for their anticipated relationship with economic growth based on other studies that have estimated the Scully/BARS Curve. The variables for this regression are all from the JST Dataset and detailed descriptions of each and their sources are available there.

Of course, as regressions are for the entire 1870 to 2013 period there is the particular issue of the volatility of data, especially during the pre-1950 period, not only because of different 
data standards and availability involved in the construction of data, but also because of the events of pre-1945. ${ }^{13}$ In particular, the period from 1914 to 1946 is marked by two world wars, the Great Depression and the Roaring Twenties. Even with controls for some of these events, there is still substantial volatility and large outliers in some years. ${ }^{14}$ As a result, the estimates are also done for outlier adjusted data to include only real GDP growth rates between -10 and 10 percent. As well, the tests and analysis were also performed for both 5year averaged and annual data. Addressing cross-country questions using 5-year averages is useful because it can filter out the effects of business cycles, reduce the effects of any year-toyear measurement error when it comes to historical statistics, and allow a longer time period for government spending to affect the economy.

The regressions are estimated using Feasible Generalized Least Squares (FGLS). Wu, You and Zou (2016) show that the problem of spurious regression can disappear if trend variables are included as additional regressors using a Feasible General Least Square (FGLS) estimator. This is considered an alternate solution to the problem of spurious regressions given the low power and inconclusive nature of stationarity tests given limited spans of data. The lagged variables also play the role of trend variables in this regression. The FGLS estimates for Canada and Italy were done for the outlier-adjusted 5-year averaged data with two different regressions with the results presented in Appendix 1 (Table A1). In these first regressions, we assume homoskedasticity and no serial correlation and in the second regression, we assume both heteroskedasticity and serial correlation ${ }^{15}$. We repeated the regression for the outlieradjusted annual data and present the final results adjusted for heteroskedasticity and serial correlation in Table 3 (with the results for homoskedasticity and no serial correlation also in Appendix 1(Table A2).

Tests were performed for serial correlation and heteroskedasticity on the outlier-adjusted annual data. We also take 5-year averages of the outlier-adjusted data and performed tests for

\footnotetext{
${ }^{13}$ There is also the issue of stationarity. Augmented Dickey-Fuller tests for Canada (with trend and three lags) found that government expenditure to GDP and GDP growth were stationary but the null hypothesis of a unit root could not be rejected for debt to GDP, long-term interest rate and the export to GDP ratio. For Italy, the null hypothesis of a unit root could not be rejected for the debt to GDP ratio, the long-term interest rate, exports to GDP, and the government expenditure to GDP ratio. However, the GDP growth rate for Italy was also found to be stationary.

${ }^{14}$ This is especially a problem for Italy given the economic collapse and high inflation during the war and then a rebound. For example, real GDP growth in 1944 is -248 percent (nominal GDP growth that year is 96 percent, and inflation is 344 percent) while in 1946 real GDP growth is +106 percent (nominal GDP growth was 124 Percent and inflation was 18 percent. Nevertheless, these extreme values were omitted for the purpose of the regressions.

${ }^{15}$ Assumed to be AR(1).
} 
DI MATTEO, BARBIERO Economic Growth and Public Sector in Canada and Italy 1870-2013

Table 3: Canada-Italy Regression Results for Outlier Adjusted* and Annual Data

\begin{tabular}{|l|r|r|}
\hline \multicolumn{3}{|c|}{ Heteroskedasticity adjusted, AR(1) } \\
\hline Government expenditure to GDP ratio & Canada** & Italy** \\
\hline Government expenditure to GDP ratio squared & $\mathbf{- 1 0 5 . 5 3}$ & $\mathbf{5 0 . 1 6}$ \\
\hline Dummy variable for World War 1 & $\mathbf{- 4 . 0 6}$ & -3.92 \\
\hline Dummy variable for World War 2 & 3.56 & -0.17 \\
\hline Government debt to GDP ratio & -2.00 & $\mathbf{- 5 . 9 8}$ \\
\hline Long term interest rates & -0.28 & 0.04 \\
\hline Export to GDP ratio & 1.10 & -12.24 \\
\hline Real Per Capita GDP Lagged One Year & 0.00 & 0.00 \\
\hline Real Per Capita GDP Growth Lagged One Year & $\mathbf{0 . 2 8}$ & -0.21 \\
\hline Great Depression & $\mathbf{- 6 . 1 0}$ & $\mathbf{- 6 . 0 5}$ \\
\hline Constant & 1.68 & 4.11 \\
\hline Wald Chi Squared & 49.67 & 58.11 \\
\hline N & 126 & 130 \\
\hline
\end{tabular}

* Dropping growth rates $>10$ percent and $<-10$ percent.

** Bold indicate significant at $1 \%$ level. Bold italics indicate significant at 5\% level. Italics indicate significant at $10 \%$ level.

heteroskedasticity and serial correlation (these are available from the authors on request). The results of the tests (when outliers are removed before averaging) suggest that there is no heteroskedasticity in both the Canadian and Italian data because the null hypothesis of homoskedasticity is not rejected for either country. As well, tests for serial correlation were performed, but they generated conflicting results, and therefore regressions were performed under assumptions both including and excluding serial correlation.

While both Table A1 and Table A2 in the appendix provide some evidence of hump/shaped Scully/BARS Curves, the outlier adjusted results presented in Table 3 using annual data generate a Scully/BARS curve that especially for Italy is the most plausible. Real GDP growth in Italy is maximized at a central government size of 33 percent with a corresponding peak real GDP growth rate of 8.18 percent whereas the other results suggest a growth maximizing size of 10 percent with a corresponding growth rate of under one percent 
which does not correspond well to the historical pattern. ${ }^{16}$ Using the results in Table 3 estimated under the assumption of heteroskedasticity and first order autocorrelation in the panels, Figure 1 plots the separate Scully Curves for Canada and Italy.

The results show a hump-shaped Scully/BARS curve for both Canada and Italy. Using the results adjusted for heteroskedasticity and first order autocorrelation, Canada demonstrates a Scully Curve relationship between public sector size and the growth rate of GDP with one of the coefficients significant at least at the 10 percent level. Indeed, all other things given, real GDP growth in Canada is maximized at a central government size of 22 percent with corresponding real GDP growth at 5.16 percent. ${ }^{17}$ It should be noted that this result is based on historical numbers spanning the entire macroeconomic history of Canada and therefore should be considered as an average approximate size of economic growth maximizing government.

Figure 1: Scully/BARS Curves for Canada \& Italy

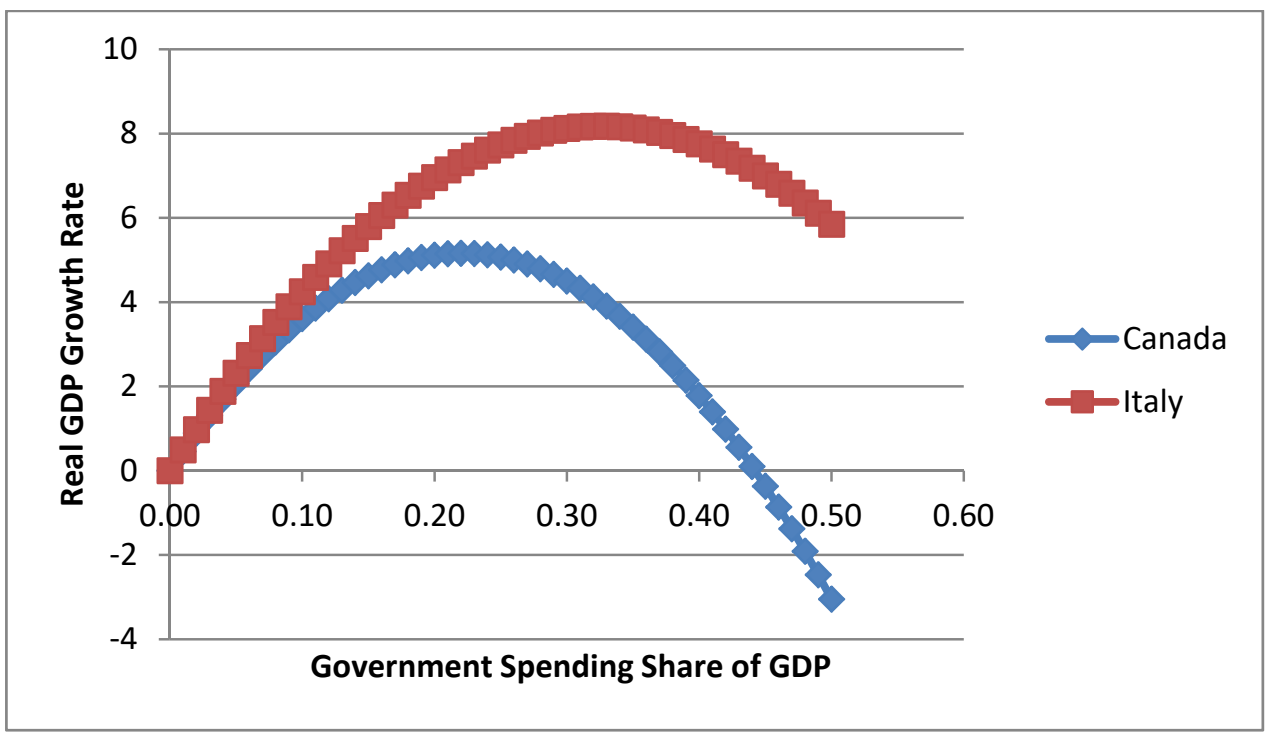

\footnotetext{
${ }^{16}$ For example, the results in $\mathrm{A} 1: \mathrm{A}$ and $\mathrm{A} 1: \mathrm{B}$ show the economic growth maximizing size of Italian government at just under 10 percent with growth rates below one percent and negative economic growth rates soon after. Moreover, the Italian coefficients for government size are not very significant.

${ }^{17}$ It should be noted that a more statistically significant Scully curve for Canada is generated using the 5-year average data and the heteroskedasticity-serial correlation adjusted curve in Appendix 1 generates a growth maximizing size of government for Canada at 22 percent with a growth rate of 8.3 percent.
} 
Given that the public sector variable is central government expenditure to GDP and that the federal public sector to GDP ratio in Canada was approximately 14 percent by 2013, while total public sector size was about 40 percent of GDP, this suggests that Canada's federal public sector is presently below its long-term GDP growth maximizing size. With respect to other variables, World War One had a negative effect (only at the $10 \%$ level) on economic growth in Canada while the Great Depression showed a significantly (at the $1 \%$ level) negative shock. Other variables were not very significant.

The results for Italy also find a Scully curve with at least one coefficient significant at the 10 percent level. Real GDP growth in Italy is maximized at a central government size of 33 percent -significantly larger than for Canada-with a corresponding peak real GDP growth rate of 8.18 percent. The Great Depression and the government debt to GDP ratio also were significant negative correlates of real GDP growth. The results for Italy show a growth maximizing public sector size larger than that for Forte and Magazzino (2011), which are done for the period 1861 to 2008 using a total government expenditure to GDP measure of public sector size. They find output growth for the period 1861 to 2008 maximized at total government expenditure to GDP ratio of only 21 percent. ${ }^{18}$

The difference between our results and the Forte and Magazzino results may lie in the different government expenditure data and time spans employed. For example, they use a measure of total government expenditure as opposed to central government spending. As well, Forte and Magazzino use data spanning the period 1861 to 2008 whereas our results use data spanning 1870 to 2013. According to Toniolo (2012) the period from 1861 to 1896 in Italy was exceptionally sluggish in terms of economic growth as was the period since 1992. Our data range by starting in 1870 excludes a decade of slow growth on the front end and by continuing after 2008 adds quite of few years of very slow growth and quite high government spending as a result of the 2008-09 financial crisis. While the differences in data span may seem minor, they may be part of the reason for the difference in the results. Another reason may simply be the difference in model specifications and estimation techniques. The Forte and Magazzino regressions include variables we do not employ such as unemployment rate, population and fiscal reform variables in their models as well as time period breaks for the pre and post-World War II period.

Given that the public sector size in Italy measured as central government expenditure to GDP by 2013 was about 30 percent, the results suggest that Italy's central government is slightly smaller than it should be for maximizing economic growth based on past Italian economic performance. At the same time, the real GDP growth rate associated with this is about 8 percent, which suggests that Italy's current economic performance lies well outside that which would be predicted by its Scully/BARS curve relationship.

\footnotetext{
${ }^{18}$ Forte and Magazzino (2011: Table 5).
} 
Real GDP growth in Canada is maximized at a central government size of 22 percent with corresponding real GDP growth at 5.16 percent and currently has a central government size of about 14 percent of GDP while real GDP growth over the period 2000 to 2013 averaged 2.8 percent. Italy on the other hand maximizes real GDP growth at a public sector size of 33 percent - larger than for Canada-with a corresponding peak real GDP growth rate of 8.18 percent but currently has a central government share of GDP at 30 percent with real GDP growth over the period 2000 to 2013 averaging -0.4 percent.

The Scully curves for Canada and Italy highlight a glaring difference: in the case of Canada growth is maximized when the central government spending is 22 percent versus 33 percent for Italy. Why such a large difference? We suggest that this disparity is rooted in the federal nature of Canada. Canada's federal government over the last 150 years has occupied a declining share of total government expenditure, with the exception of large spikes during the two world wars and immediate post-war periods. This would suggest that the federal role in economic growth maximization would have been greater in the period prior to WWII when it invested heavily in transportation infrastructure. In the post WWII period, transfers rather than spending on goods and services have become more important and these have occupied a larger role of federal spending while the provinces and local governments have focused more on redistribution expenditures such as health, education and welfare. Since 2000, Canadian federal government spending as a percentage of total government spending has ranged between 35 and 40 percent whereas during the immediate post World War Two era and into the 1960 s it was closer to two thirds. ${ }^{19}$

In contrast, Italy's central government spending has always been larger compared to the spending of its regional governments. The role of the central government was very important in the post WWII period, when the Italian post war economic miracle and growth boom occurred. In recent years, for example, central government spending has hovered around 70 percent of total government spending, an amount twice that of Canada ${ }^{20}$.

\section{Discussion}

That Canada's public sector as measured by the central government to GDP ratio is below the economic growth maximizing size may seem odd given that total public sector size in Canada is close to 40 percent of GDP. However, what this may perhaps mean is that it is also the distribution and composition of expenditures across the federal and provincial governments that may be a factor in Canadian economic growth. The estimates refer to central government

\footnotetext{
${ }^{19}$ Government of Canada, Finance Department, Fiscal Reference Tables, various years

${ }^{20}$ See the OECD data for Italy: https://www.oecd.org/regional/regional-policy/profile-Italy.pdf
} 
expenditure and perhaps a larger federal economic role for Canada may be growth enhancing. With total government expenditure to GDP at about 40 percent, a larger federal share also can imply that there should be a smaller provincial-local share.

The economic role of Canada's federal government has changed over time. From an infrastructure role involving subsidization of transport networks, Canada has decentralized since the end of the Second World War and the federal government's spending has become more focused on individual and intergovernmental transfers rather than purchases of goods and services. ${ }^{21}$ Prior to 1945, government in Canada was smaller as a share of GDP but much federal spending was on goods, and especially infrastructure spending, particularly during the railway building eras of the late nineteenth and early twentieth centuries. While spending on health and education and redistribution has grown in Canada over time, much of that is at the provincial level, albeit partly financed by federal transfer payments.

Given the shift in the composition of Canadian federal government spending over time and the evidence that the federal expenditure to GDP ratio may be below the growth maximizing point, one possible policy prescription for Canada's federal government if it wishes to enhance economic growth would be to boost federal spending on physical infrastructure and perhaps reduce the amount going primarily to transfers. Given Canada's high per capita income and state of economic development and relatively robust growth within the G-7, the policy prescription would at best involve some relatively minor tweaking of the federal expenditure role.

The Italian case is more curious and complex. The results for Italy suggest that at present, the Italian central government size is slightly below its growth maximizing size. At the same time, the real GDP growth rate associated with that size is approximately 8 percent and Italy's economic performance over the last 25 years has been nowhere near that point. Indeed, one can make the case that Italy's current economic performance is off of or disconnected from, its historical Scully Curve. At the same time, it should be noted that Italy's Scully Curve peak is a function of its extraordinary rapid economic performance from 1945 to the mid1980s.

Italy's economic performance is cause for concern not only based on comparisons with Canada and other G-7 countries, but also with respect to its own historical performance. Clearly, increasing Italy's central government size from 30 to 33 percent is unlikely to close the gap between growth currently averaging -0.4 percent and peak performance of 8 percent. We also need to keep in mind that gross government sector debt as a share of GDP in 2015 was 157 percent for Italy and 107 percent for Canada, limiting the ability for public sector spending increases.

21 See Di Matteo (2017) for a discussion. 
What factors could account for this gap in performance between Canada and Italy? Notwithstanding the fact of differences in endowments and resources whose long-term effect is captured in the lagged output variables, such a comparison of two advanced industrialized countries also provides a natural experiment as to how different policy choices can impact economy growth. While differing rates of economic growth may have many ingredients, one difference that stands out in comparing Canada and Italy is the redistribution of income through social and redistributive spending at both the individual and regional level.

While there are regional disparities in both Canada and Italy, a much smaller proportion of Canada's population lives in relatively economically lagging parts of the country compared to Italy. For example, in Canada approximately 2.3 million people, or just over 6 percent of the population, live in the more transfer dependent Atlantic provinces. In Italy, approximately 14 million people, or 23 percent of the population, live in the more transfer dependent south of Italy. The result when it comes to government spending in excess of that needed to assist in economic development and growth is that Italy spends significantly more, and the difference is quite noticeable when one examines social spending. However, the key difference is in income transfers rather than the provision of public goods in health and education.

According to the OECD, when it comes to education spending as a share of total government spending, Canada and Italy are comparable at 20 and 22 percent respectively. Public health spending levels are also not greatly out of sync as government health spending as a share of GDP is currently 7.2 percent in Canada and 6.5 percent in Italy, while per capita government health spending in USD is $\$ 3,262$ in Canada and $\$ 2,470$ in Italy. Yet, overall social spending in Italy is the $4^{\text {th }}$ highest of the OECD countries at 28.9 percent of GDP versus 17.2 percent in Canada. The difference is driven by social benefits to households, which are 21 percent of GDP in Italy versus 10 percent in Canada, of which pensions is a big proportion in Italy. Government spending on pensions in Canada is 4.5 percent of GDP compared to 16.3 percent of GDP in Italy, compared to an OECD average of 8.2 percent.

Public policy matters a great deal in the performance of the economy and a key difference between the two economies when it comes to public sector performance is the difference in size and emphasis of social spending. One contributing factor for the relatively stagnant Italian economy over the last quarter century is the high percentage of government spending not on health and education but income transfers. This difference is ultimately the result of political decisions that have had long-term economic consequences for the Italian economy's performance.

There is a well-known trade-off between efficiency and equity. The efficient size of government can indeed vary from country to country, as we saw in our literature review, even if there is a consensus that after a certain point, more government spending impacts economic growth negatively. The relative high percentage of national output going to pensions in Italy compared to Canada is a way to a more equitable distribution of income, at the very least 
between those over a certain age and younger workers. But with an aging population, pension payments will become an ever-increasing burden on younger age groups through higher taxes, with negative consequences for economic incentives.

While public policy has favoured more resources going to pensions in Italy $^{22}$, the interesting question is why? A possible answer is provided by Olson $(1965,1982,2000)$, who maintains that in a growing economy the formation of interest groups over time, both in and out of the public sector, such as protectionist policies and "redistributional coalitions," will in the long-run retard economic performance. He theorized that in situations where collective action is necessary, interest groups arise that try to appropriate benefits and diffuse costs over the wider group. As a group becomes larger, as in the case of the nation state, the free rider problem will concentrate the benefits to the smaller interest group. Groups such as industry or employment interests have an incentive to form lobby groups to promote beneficial policies which often can be protectionist or redistributive, and while generating specific benefits to the group, can harm economic growth in the long run. As these distributional coalitions become more rooted and powerful, economic growth declines and indeed can result in the economic decline of entire nations. ${ }^{23}$

We do not want to imply that distributional policies are solely responsible for the poor growth performance in Italy, or that the relatively good performance of the Canadian economy over the same time horizon. For the Italian economy, an aging population, suboptimal size of business firms ${ }^{24}$, and family structure ${ }^{25}$ has also been blamed. Nevertheless, the correlation between greater distributional policies and lower economic growth suggest that they have been a factor of some consequence.

\section{Conclusions}

We have investigated the long-run association between central government spending and economic growth in two G7 countries. We find a hump-shaped Scully/BARS curve for both Canada and Italy. After controlling for a set of confounding factors, real GDP growth in Canada is maximized at a central government public sector size of 22 percent with corresponding real GDP growth at 5.16 percent.; in Italy real GDP growth is maximized at a central government public sector size of 33 percent, with a corresponding peak real GDP growth rate of 8.18 percent. These results are impacted by the historical GDP growth rates in both countries. Italy's economy grew exceptionally fast in the first two decades after WWII

\footnotetext{
${ }^{22}$ For a discussion on how culture can impact national institutions, including the case of Italy, see Alesina and Giuliani (2015).

${ }^{23} \mathrm{We}$ are not the first to suggest this argument for the case of Italy. See Beckman (2013)

${ }^{24}$ See Pellegrino and Zingales (2014)

${ }^{25}$ See Alesina and Giuliano (2007),
} 
and explains the higher estimated peak growth rate of over 8 percent though such a rate is outside the range of current experience.

We would not expect either Canada or Italy to achieve the same peak growth rates as in the past, even if both had the growth maximizing size central government. We noted that the different growth maximizing size of central government spending as a percentage of GDP is substantially different in Canada compared to Italy because of different roles of the central government. In Canada the central government accounts for between 35 and 40 percent of total government spending, whereas in Italy the central government accounts for about double that amount. Indeed, a less decentralized governmental system may also be a factor in current sluggish Italian economic performance.

Our findings relate to central government expenditures and do not consider the expenditures of the provinces/regions or the municipalities in each country. Future studies should concentrate on determining the Scully/BARS curve for the two countries with the spending of all levels of government. Nevertheless, these results also hint that some of the adjustment in public sector spending with regards to affecting economic growth could involve a redistribution across tiers of government particularly in the Canadian case.

The comparison between Canada and Italy also clearly highlights the very slow growth in the economy of the latter in the last 25 years. Italy poor growth performance is disappointing also compared to its own past economic performance, particularly in the post-World War II era. We provided a tentative explanation for the unusually slow growth, connected with government expenditures focused on the higher distributional content of these expenditures.

\section{References}

Abdiweli, A.M. (2003), Institutional Differences as Sources of Growth Differences, Atlantic Economic Journal, Vol. 31, No. 4, 348-362.

Afonso, A. and D. Furceri (2010), Government Size, Composition, Volatility and Economic Growth, European Journal of Political Economy, Vol 26, No. 4, 517-532.

Afonso, A. and J.T. Jalles (2011), Economic Performance and Government Size, European Central Bank, Working Paper Series, No. 1399, November.

Ajzenstat, J. (2010), Confederation and Individual Liberty, MacDonald-Laurier Institute.

Alesina, A. and Giuliano, P. (2015), Culture and Institutions, Journal of Economic Literature, Vol. 53, No. 4, 898-944.

Alesina, A. and Giuliano, P. (2007), The Power of the Family, NBER Working Paper No. 13051

Armey, Richard K. (1995), The Freedom Revolution. Washington, DC: Regnery Publishing. Asoni, A. (2008) Protection of Property Rights and Growth as Political Equilibria, Journal of Economic Surveys, Vol. 22, No. 5, 953-987. 
DI MATTEO, BARBIERO Economic Growth and Public Sector in Canada and Italy 1870-2013

Atkinson, A.B. (1995), Is the Welfare State necessarily an obstacle to economic growth? European Economic Review, Vol. 39, 723-730.

Barro, Robert J. (1990), Government Spending in a Simple Model of Endogenous Growth. Journal of Political Economy, Vol. 98 No. 5, 103-125.

Barro, Robert J. (1991), Economic Growth in a Cross Section of Countries'. Quarterly Journal of Economics, Vol 56, 407-43.

Beckman, K.(2013) Narrow Interest Groups Schacke EU and Japanese Recoveries, Conference Board of Canada http://www.conferenceboard.ca/economics/ hot_eco_topics/default/13-12-10/narrow_interest_groups_shackle_eu_and_japanese recoveries.aspx

Bergh, A.and Henrekson, M. (2011), Government Size and Growth: A Survey and Interpretation of the Evidence, Research Institute of Industrial Economics, IFN Working Paper No. 858.

Bergh, A. and M. Karlsson (2010), Government Size and Growth: Accounting for Economic Freedom and Globalization, Public Choice, Vol. 142, Issues 1-2, 195-213.

Blanchard, O., and Perotti, R.(2002), An Empirical Characterization of the Dynamic Effects of Changes in Government Spending and Taxes on Output,' The Quarterly Journal of Economics, (November), 1329-68.

Chenery, H. B. (1962), Development Policies for Southern Italy, The Quarterly Journal Of Economics, Vol 74, No.4, 517-547.

Colombier, C. (2009), Growth Effects of Fiscal Policies: An Application of Robust Modified M-Estimator. Applied Economics, Vol. 41, No. 7, 899-912.

Di Matteo, L. (2017), A Federal Fiscal History, Canada 1867-2017, Fraser Institute.

Facchini, F. and Melki, M. (2013), Efficient government size: France in the 20th century, European Journal of Political Economy, Vol. 31, 1-14.

Ferris, J.S. and Voia, M.C. (2015), The effect of federal government size on private economic performance in Canada: 1870 -2011, Economic Modelling, Vol. 49, 172-185.

Folster, S. and Henrekson, M. (2001), Growth Effects of Government Expenditure and Taxation in Rich Countries, European Economic Review Vol 45, 1501-20.

Forte, F., and Magazzino, C. (2016), Government Size and Economic Growth in Italy: A Time Series Analysis, European Scientific Journal, March, Vol 12, No. 7, 149-69.

Forte, F., and Magazzino, C. (2011), Optimal Size Government and Economic Growth in EU Countries, Journal of Analytical and Institutional Economics, Vol. XXVIII, No. 3, 295 321.

Grier, K.B. and Tullock, G. (1989), An Empirical Analysis of Cross-National Economic Growth, 1951-1980, Journal of Monetary Economics, Vol. 24, 259-276.

Grossman (1988), Growth in government and economic growth: The Australian experience, Australian Economic Papers, Vol 27, 33-43. 
Hinton, M., Barbiero, T. and Kim, M.S. (2014), How Powerful Was the National Policy? The Lessons of the Cotton Mills, Review of Economic Analysis, Vol.6, No.1

La Forest, G.V. (1967), The Allocation of Taxing Power under the Canadian Constitution. Toronto. Canadian Tax Foundation.

Landau, D. (1983), Government expenditure and economic growth: a cross-country study, Southern Economic Journal, Vol. 49, 783-92.

Lutz, V. (1962), Italy: A Study in Economic Development, Royal Institute of International Affairs and Oxford University Press.

Marlow, M.L. (1986), Private sector shrinkage and the growth of industrialized economies, Public Choice, Vol. 49, 143-154.

Mingardi, A. (2017), Classical Liberalism in Italian Economic Thought from the Time of Unification, Econ Journal Watch, Vol. 14 No. 1, 22-54.

North, D. C. (1987), Institutions, Transaction Costs and Economic Growth. Economic Inquiry, Vol. 25, No.3,: 419-428.

North, D. C. (1990), Institutions, Institutional Change and Economic Performance, Cambridge University Press.

OECD, (2016), National Accounts Statistics, Italy, Unitary country, https://www.oecd.org/regional/regional-policy/profile-Italy.pdf

Olson, M. (1965), The Logic of Collective Action: Public Goods and the Theory of Groups, Cambridge, MA: Harvard University Press. 1965.

Olson, M. (1982), The Rise and Decline of Nations: Economic Growth, Stagflation, and Social Rigidities, New Haven: Yale University Press. 1982

Olson, M. (2000), Power and Prosperity: Outgrowing Communist and Capitalist Dictatorships, New York: Basic Books.

Pellegrino, B. and Zingales, L. (2014), Diagnosing the Italian Disease, Unpublished manuscript, September 2014.

Ram, R. (1986), Government size and economic growth: A new framework and some evidence from cross-section and time series data. American Economic Review, 76, March, 191-203.

Rodrik, D. (2007), One Economics, Many Recipes: Globalization, Institutions, and Economic Growth, Princeton University Press.

Rodrik, D.Subramanian, A. and Trebbi, F. (2004), Institutions Rule: The Primacy of Institutions over Geography and Integration in Economic Development, Journal of Economic Growth, Vol. 9, No. 2, 131-165.

Romer, P. M. (1994), The Origins of Endogenous Growth, Journal of Economic Perspectives, Vol. 8, No. 1, 3-22. 
DI MATTEO, BARBIERO Economic Growth and Public Sector in Canada and Italy 1870-2013

Romero-Avila, D. and Strauch, R. (2008), Public finances and long-term growth in Europe: Evidence from panel data analysis, European Journal of Political Economy, Vol. 24, 172191.

Rubinson, R. (1977), Dependency, government revenue and economic growth: 1955-1970, Studies in Comparative International Development, Vol. 12, 3-28.

Scully, G. (2000), The growth-maximizing tax-rate, Pacific Economic Review, Vol. 5, 93-96.

Scully, G. W. (1989), The Size of the State, Economic Growth and the Efficient Utilization of National Resources, Public Choice, Vol. 63, 149-64.

Scully, G. (1994), What is the optimal size of government in the US? Policy Report 188. National Center for Policy Analysis.

Scully, G. (1991), Tax Rates, Tax Revenues and Economic Growth, Policy Report No. 98. Dallas: National Center for Policy Analysis.

Slemrod, J. (1995), What Do Cross-Country Studies Teach About Government Involvement, Prosperity, and Economic Growth? Brookings Papers on Economic

Activity, Vol. 2, 373-431.

Solow, R. M. (1994), Perspectives of Growth Theory, Journal of Economic Perspectives, Vol. 8 , No. $1,45-54$.

Sturm, J.E. and De Haan, J. (2001), How robust is the relationship between economic freedom and economic growth, Applied Economics, Vol. 33, No. 7, 839-844.

Swan, T. W. (1956), Economic Growth and Capital Accumulation. Economic Record, 32 (2): 334-361.

Tanzi, V. (2011), Government versus Markets: The Changing Economic Role of the State, Cambridge: Cambridge University Press.

Tanzi, V. (2005), The Economic Role of the State in the $21^{\text {st }}$ Century, Cato Journal, Vol. 25, No. 3, 617-638.

Tanzi V. and Zee, H. (1997), Fiscal policy and long-run growth, IMF Staff Papers, Vol. 44, 179-209.

Toniolo, G. (2012), Italy's Economic Growth: An Overview, Chapter 1. In Toniolo, G.i (ed), The Oxford Handbook of the Italian Economy Since Unification, New York, Oxford University Press

Wu, M., You, P., and Zou, N. (2016), On spurious regressions with trending variables. arXiv preprint arXiv:1606.05049. 
Review of Economic Analysis 10 (2018) 221-243

\section{Appendix 1}

Table A1: Canada-Italy Regression Results for Outlier Adjusted and 5 Year Average Data

\begin{tabular}{|l|r|r|}
\hline \multicolumn{3}{|c|}{ A1: A Homoskedasticity, no serial correlation $* *$} \\
\hline Government expenditure to GDP ratio & Canada & \multicolumn{1}{l|}{ Italy } \\
\hline Government expenditure to GDP ratio squared & $\mathbf{7 4 . 9 9}$ & 10.16 \\
\hline Dummy variable for World War 1 & $-\mathbf{1 6 9 . 6 8}$ & -46.97 \\
\hline Dummy variable for World War 2 & -1.02 & 4.53 \\
\hline Government debt to GDP ratio & 5.09 & $\mathbf{7 . 9 4}$ \\
\hline Long term interest rates & -4.22 & 2.30 \\
\hline Export to GDP ratio & -0.28 & $\mathbf{0 . 3 6}$ \\
\hline Real Per Capita GDP Lagged One Year & -6.96 & -12.52 \\
\hline Real Per Capita GDP Growth Lagged One Year & 0.00 & 0.00 \\
\hline Great Depression & $\mathbf{0 . 7 7}$ & $\mathbf{1 . 2 2}$ \\
\hline Constant & -0.21 & $\mathbf{- 2 . 5 0}$ \\
\hline Wald Chi Squared & 0.41 & -3.24 \\
\hline N & 136.72 & 130.22 \\
\hline
\end{tabular}

A1: B Heteroskedasticity and Serial Correlation **

\begin{tabular}{|l|r|r|}
\hline & Canada & \multicolumn{1}{l|}{ Italy } \\
\hline Government expenditure to GDP ratio & $\mathbf{7 3 . 9 9}$ & 6.84 \\
\hline Government expenditure to GDP ratio squared & $-\mathbf{1 6 5 . 3 5}$ & -50.92 \\
\hline Dummy variable for World War 1 & -0.80 & $\mathbf{6 . 2 0}$ \\
\hline Dummy variable for World War 2 & 5.09 & $\mathbf{8 . 7 1}$ \\
\hline Government debt to GDP ratio & -4.21 & $\mathbf{2 . 5 8}$ \\
\hline Long term interest rates & -0.28 & $\mathbf{0 . 4 4}$ \\
\hline Export to GDP ratio & -8.77 & -17.73 \\
\hline Real Per Capita GDP Lagged One Year & 0.00 & 0.00 \\
\hline Real Per Capita GDP Growth Lagged One Year & $\mathbf{0 . 7 6}$ & $\mathbf{1 . 2 8}$ \\
\hline Great Depression & -0.19 & $-\mathbf{2 . 5 8}$ \\
\hline Constant & 0.66 & -3.17 \\
\hline Wald Chi Squared & 143.54 & 179.53 \\
\hline N & 29 & 29 \\
\hline
\end{tabular}

Note: Bold indicates significant at $1 \%$ level. Bold italics indicate significant at $5 \%$ level. Italics indicate significant at $10 \%$ level. 
DI MATTEO, BARBIERO Economic Growth and Public Sector in Canada and Italy 1870-2013

Table A2: Canada-Italy Regression Results for Outlier Adjusted and Annual

\begin{tabular}{|c|c|c|}
\hline \multicolumn{3}{|c|}{ A2: A. Homoscedastic, no autocorrelation ** } \\
\hline & Canada & Italy \\
\hline Government expenditure to GDP ratio & 45.91 & 50.18 \\
\hline Government expenditure to GDP ratio squared & -104.63 & -76.92 \\
\hline Dummy variable for World War 1 & -4.55 & -3.92 \\
\hline Dummy variable for World War 2 & 3.66 & -0.18 \\
\hline Government debt to GDP ratio & -2.27 & -5.98 \\
\hline Long term interest rates & -0.28 & 0.04 \\
\hline Export to GDP ratio & 3.50 & -12.21 \\
\hline Real Per Capita GDP Lagged One Year & 0.00 & 0.00 \\
\hline Real Per Capita GDP Growth Lagged One Year & 0.22 & -0.21 \\
\hline Great Depression & -6.46 & -6.05 \\
\hline Constant & 1.68 & 4.11 \\
\hline Wald Chi Squared & 39.41 & 58.15 \\
\hline$N$ & 126 & 130 \\
\hline
\end{tabular}

Note: Bold indicates significant at $1 \%$ level. Bold italics indicate significant at $5 \%$ level. Italics indicate significant at $10 \%$ level. 